1118

\title{
二次流れのカオス化を利用したマイクロミキサの実験的研究 (混合に及ぼす流路の回転効果)
}

\author{
Experimental Study of the Micromixer Using the Chaos of Secondary Flow \\ (Rotation Effect of Channel on the Mixing)
}

学 安田 直幸（米子高専専攻科）, 正 早水 庸隆（米子高専）, 学 西田 五徳（岡山大院）, 正 森田 慎一 (米子高専) , 正 大塚 茂, 正 柳瀬 眞一郎（岡山大工），正 山本 恭二

Naoyuki YASUDA, Yonago National College of Technology Advanced Course, 4448 Hikona-cho, Yonago-shi, Tottori 683-8502, Japan Yasutaka HAYAMIZU, Yonago National College of Technology, 4448 Hikona-cho, Yonago-shi, Tottori 683-8502, Japan

Kazunori NISHIDA, Okayama University, 3-1-1 Tushimanaka, Okayama-shi, Okayama 700-8530, Japan

Shinichi MORITA, Yonago National College of Technology, 4448 Hikona-cho, Yonago-shi, Tottori 683-8502, Japan

Shigeru OHTSUKA, Yonago National College of Technology, 4448 Hikona-cho, Yonago-shi, Tottori 683-8502, Japan

Shinichiro YANASE, Okayama University, 3-1-1 Tushimanaka, Okayama-shi, Okayama 700-8530, Japan

Kyoji YAMAMOTO, Okayama University, 3-1-1 Tushimanaka, Okayama-shi, Okayama 700-8530, Japan

Key Words: Micromixer, Secondary Flow, Chaos, PIV, LIF

\section{1. 緒言}

近年, 化学やバイオなどの分野において化学分析などの化 学操作を小さなチップ上に集積した $\mu$-TAS (Micro Total Analysis Systems）と呼ばれる超小型・化学分析装置の開発が 注目されている。この装置はさまざまなマイクロ流体素子や センサなどからなり, 混合, 攪拌, 反応, 分離や抽出などの 一連の操作を行う。しかし，流路はマイクロサイズであるた め, その流れは低レイノルズ数となり乱流による攪拌や熱移 動が期待できない. そのため, 低レイノルズ数流れにおいて 効率よく混合・攪拌されるマイクロ流体デバイスが必要とさ れている，そこで，本研究では流路壁の一部が回転する曲が り流路により二次流れをカオス化させ，混合・攪拌の促進を 図るマイクロミキサの開発を目的とする。

本報告では, 曲がり流路断面のアスペクト比の違いによる 2 液の混合に及ぼす影響について二次流れの PIV 及び LIF 計 測結果から検討する.

\section{2. 記号及び関連する実験式}

本実験は，これまでに研究していた曲がり流路断面が正方 形断面となる Mixer I に加え，曲がり流路断面がそれぞれ横 長となる Mixer II と縦長になる MixerIIIを用いて，曲がり流 路断面のアスペクト比の変更による 2 液の混合に及ぼす影響 を調べる。実験で使用した実験装置の各寸法を表 1 に示寸. $2 a$ は流路幅 $[\mathrm{mm}], \quad 2 b$ は流路高さ $[\mathrm{mm}], \quad R$ は流路の曲率半径 $[\mathrm{mm}], \delta=a / R$ は流路の無次元曲率, $\gamma=b / a$ は流路断面のアス ペクト比, l は流路全長 $[\mathrm{mm}]$ である.

Table 1 Dimensions of curved channel

\begin{tabular}{|c|c|c|c|c|c|c|}
\hline & $2 a[\mathrm{~mm}]$ & $2 b[\mathrm{~mm}]$ & $R[\mathrm{~mm}]$ & $\delta$ & $\gamma$ & $l[\mathrm{~mm}]$ \\
\hline Mixer I & 3 & 3 & 15 & 0.1 & 1 & 58.9 \\
\hline Mixer II & 4.5 & 2 & 22.5 & 0.1 & 0.44 & 88.4 \\
\hline MixerIII & 2 & 4.5 & 10 & 0.1 & 2.25 & 39.3 \\
\hline
\end{tabular}

実験では, 流路を流れる流量 $Q\left[\mathrm{~mm}^{3} / \mathrm{s}\right]$, ロータの角速度 $\Omega[\mathrm{rad} / \mathrm{s}]$ から，それぞれレイノルズ数 $R e=q d_{h} v$ ，テイラー 数 ${ }^{(1)} T r=2(2 \delta)^{1 / 2} \Omega a^{2} /(\delta v)$ の無次元数を求めた. ここで, $q$ は流 路内平均流速 $[\mathrm{mm} / \mathrm{s}], d_{h}=4 a b /(a+b)$ は水力直径 $[\mathrm{mm}], v$ は作 動流体の動粘度 $\left[\mathrm{mm}^{2} / \mathrm{s}\right]$ である．Tr は作動流体が流れる方向 と同方向にロータを回転させる場合を正としている．また， 曲がり流路において $\delta$ 違いによる流量の違いを考慮するた
めに曲がり流路層流パラメータであるディーン数 ${ }^{(2)}$ $D e=R e \delta^{1 / 2}$ を用いた。

\section{3. 実験方法}

実験の手順としては，まず，図１のタンク（1)，(2)にそれぞ れ試料である作動流体 (グリセリン水溶液 $70 \mathrm{wt} \%$ とグリセリ ン水溶液 $70 \mathrm{wt} \%$ にレーザ蛍光染料であるローダミン B を濃 度 $2.5 \mathrm{ppm}$ で溶解したもの) を溜め，ポンプ(3)，(4)により才 ーバーフロータンク (5), (6)一輸送する．２液は流路(7)で合流 し，そのまま試験部である曲がり流路(9)人流れ込みバルブ (10で流量を調整し排水される. 試験部へ 2 液はそれぞれ縦に 2 層となるように同量流入させる. 流量は, 出口から流出す る重量を測定し, 重量法により算出した. 試験部のロータの 駆動には，モータ88用いた。試験部の流路はロータとケー シングで形成しており，流路の上壁面と内壁がロータである (図 2 参照)。(11)可視化の際に光の屈折を緩和し二次流れ を見やすくするための水で満たしたビューイングブロック である。PIV 及び LIF 計測には Davis7.2（LaVision 社）を用 い, PIV 用のトレーサには比重 1.1 の中空ガラス粒子（粒子

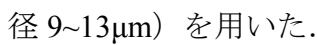

可視化方法は図 2 のように, 流路側面を波長 $532 \mathrm{~nm}$ の CW レーザシート（LaVision 社:CW-532-3W）で照らし, 流路断 面をハイスピードカメラ (LaVision 社: HSS4G) で撮影した. 撮影位置は図 2 のように曲がり流路入口から $180^{\circ}$ の位置で 行った. PIVを行う場合は，バンドパスフィルタ（中心波長 $532 \mathrm{~nm}$, 半值全幅 $10 \mathrm{~nm}$ ) をつけガラス粒子のみの像を取得 し速度分布を算出した. LIF を行う場合は, ハイパスフィル タ（透過波長 $570 \mathrm{~nm}$ 以上）をつけローダミン B の蛍光のみ を取得し濃度分布を算出した。

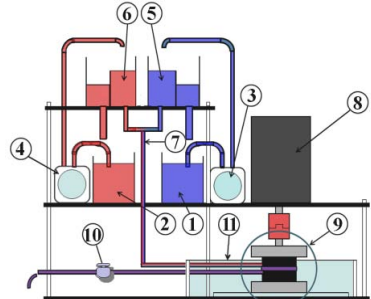

Fig.1 Experimental setup

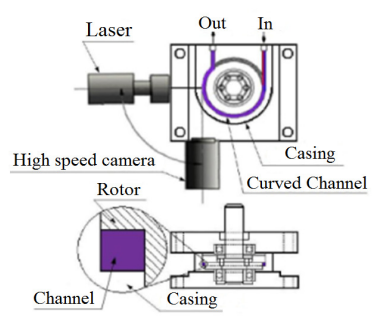

Fig.2 Method of visualization 


\section{4. 実験結果}

\section{1 二次流れ}

図 3 に Mixer I , Mixer II, MixerIIIにおける $T r=3, D e=0.3$ の LIF，PIV 結果をそれぞれ示す。それぞれ( i )が LIF, (ii) が PIV の結果であり，画像の右と上側がロータ壁面，左と下 側がケーシング壁面である。また，ローダミン B で染色され たグリセリン水溶液が二次流れ断面において右側に来るよ うに撮影した。 LIF 計測結果の右横にはそれぞれローダミン B で染色されたグリセリン水溶液の濃度を示しており, 濃度 $50 \%$ 付近の領域が増加することにより，混合が促進されてい ると評価する.

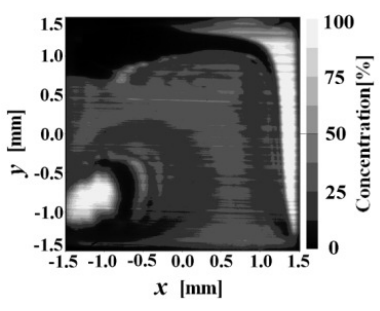

(i ) LIF

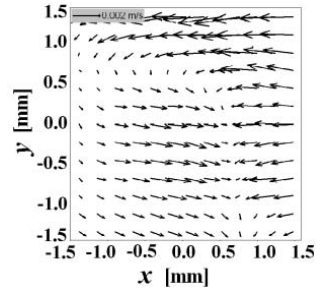

(ii) PIV (a) Mixer I

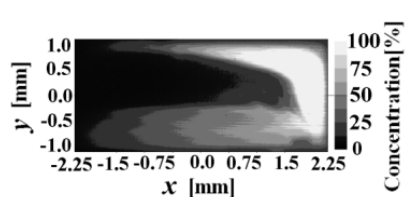

(i ) LIF

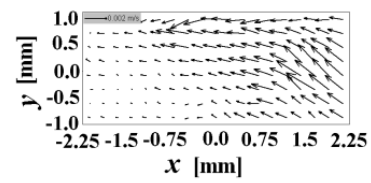

(ii ) PIV (b) Mixer II

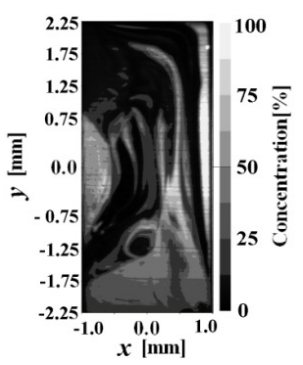

(i ) LIF

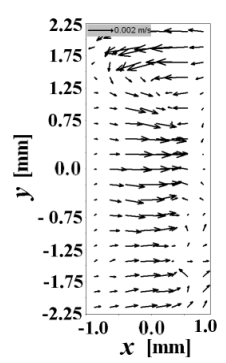

(ii ) PIV (c) Mixer III

Fig. 3 Secondary flow pattern at $T r=3$ and $D e=0.3$

曲がり流路の断面が正方形断面となる Mixer I の LIF 結果 を見ると, ロータの回転の影響により 2 液は層を形成せず複 雑化している．PIV 結果を見ても二次流れは複雑化し，時間 発展に対しカオス的な変化をする.さらにDe が小さくなる とロータの回転の影響は強まり，Mixer I においては $D e \leq 0.1 T r$ という関係において混合が促進されることが分か った．また，Mixer I と Mixer II の LIF 結果を比較すると，同 じ De $\operatorname{Tr}$ にも関わらず Mixer II においては Mixer I のように 混合促進されていない. PIV 結果を見ても Mixer I に比べて 弱い二次流れとなっている. 次に Mixer I と MixerIII の LIF 結果を比較すると, MixerIIIは同じ $D e$ と $T r$ の関係で混合が 促進され, 二次流れの構造も複雑である. PIV 結果では, Mixer I でも見られるケーシング壁面（左側）からロータ壁 面（右側）への流れが MixerIIIではより発達しており，広い 範囲で発生している.

\section{2 軸流速度}

本実験ではさらに撮影角度を変更し，曲がり流路における 軸流速度の PIV 計測を行なった. その PIV 計測結果をもとに 作成した軸流速度分布を図 4 に示す.グラフの縦軸は時間平 均軸流速度 $w[\mathrm{~m} / \mathrm{s}]$, 横軸は流路幅 $x[\mathrm{~mm}]$ （図 3 の横軸）で
あり，各プロットは撮影位置（図 3 の縦軸）を示している. また，図 4(a)は曲がり流路入口より $180^{\circ}$ ，図 4(b)は曲がり 流路入口より $0^{\circ}$ の位置において計測したものである.

各グラフよりすべての装置において，ロータ壁面に近づく につれ流速は増加し，ケーシング壁面に近づくにつれ流速は 減少する傾向が表れている。しかし，混合が促進されている Mixer I ，MixerIIIにおいては，ロータの回転が正回転にも関 わらず逆流が発生していることが確認できる。これは，ロー タの回転の影響が強まることで, 曲がり流路出口付近で圧力 が上昇し，流れとは逆向きの圧力勾配の発生によるものと考 えられる. $180^{\circ}$ の位置である図 3(a), (c)の二次流れの PIV 結果と比較すると, 図 4(a)の逆流が発生している位置におい て，ケーシング壁面からロータ壁面へ向かう（曲がりの内側 へ向から）二次流れが発生しており，この二次流れは逆流の 影響で発生すると思われ, 流路断面のアスペクト比が大きく なるにつれ逆流の領域は増加している. 図 4(b)を見ると, $180^{\circ}$ で見られたような逆流が， $0^{\circ}$ の位置まで到達しており, 曲がり流路全体で逆流が発生していることが分かる．特に MixerIIIでの逆流は広範囲であり，曲がり流路内で積極的な 循環が起きていると考えられる。この逆流により曲がり流路 内において発生した循環流の影響で二次流れはカオス化さ れ，循環流の影響が強いほど混合が促進されると考えられる。

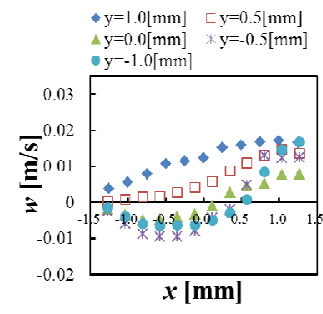

( i ) Mixer I

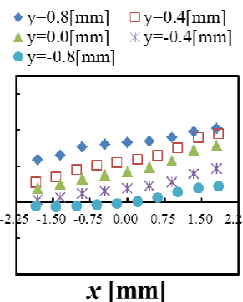

(ii ) Mixer II

(a) $180^{\circ}$

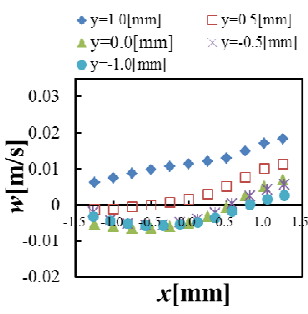

( i ) Mixer I

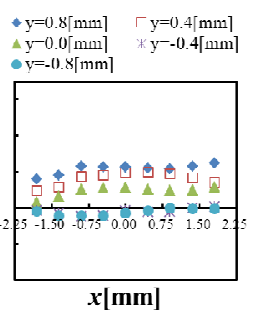

(ii ) Mixer II

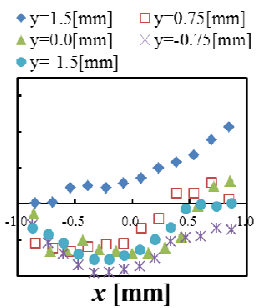

(iii) Mixer III (b) $0^{\circ}$

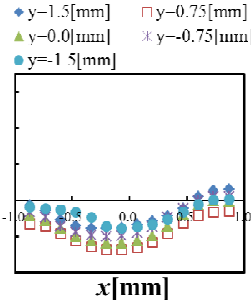

(iii) Mixer III

Fig.4 Axial velocity distribution at $T r=3$ and $D e=0.3$

\section{5. 結言}

曲がり流路断面のアスペクト比が異なるマイクロミキサ の可視化計測を行なった結果, 以下のことが明らかとなった

(1) アスペクト比 $\gamma=1$ の Mixer I と $\gamma=2.25$ の MixerIIII おいては, $D e \leq 0.1 T r$ という関係で混合は促進される

(2) アスペクト比 $\gamma$ が大きい方が混合はより促進される 傾向にある.

（3）逆流により発生する循環流の影響が二次流れのカオ ス化に関係していると考えられる。

\section{引用文献}

(1) Yamamoto,K., Wu,X., Nozaki,K. and Hayamizu,Y., "Visualization of Taylor-Dean flow in a curved duct of square cross-section" Fluid Dynamics Research, Vol.38(2006), PP.1-18.

（2）日本機械学会編，技術資料管路・ダクトの流体抵抗， (1979), pp.68-71, 日本機械学会. 